\title{
Kepemilikan Keluarga, Tata Kelola Perusahaan, dan Audit Report Lag
}

\author{
Umi Alvianti ${ }^{1}$ \\ Program Studi S1 Akuntansi \\ Bambang Moertono ${ }^{2}$ \\ Fakultas Bisnis dan Humaniora \\ Universitas Teknologi Yogyakarta, Indonesia Universitas Teknologi Yogyakarta, Indonesia \\ Rusmin $^{3}$ \\ Fakultas Bisnis dan Humaniora
Universitas Teknologi Yogyakarta, Indonesia \\ Emita Wahyu Astami4 \\ Fakultas Bisnis dan Humaniora
}

Surel: umialvianti27@gmail.com

ABSTRAK

Tata kelola perusahaan keluarga masih menjadi perhatian bagi para investor dan pemangku kepentingan lainnya. Penelitian ini menguji pengaruh kepemilikan keluarga dan tata kelola perusahaan terhadap audit report lag $(A R L)$. Sampel penelitian berupa perusahaan non-keuangan dengan dominasi kepemilikan keluarga dan terdaftar di Bursa Efek Indonesia periode 2017-2019, Dengan metode analisis kuadrat terkecil biasa dan teknik regresi berganda, hasil penelitian menunjukkan bahwa kepemilikan keluarga dan jumlah dewan komisaris mampu mendorong auditor menyelesaikan laporan hasil audit lebih cepat. Sedangkan kehadiran dewan komisaris independen dan komite audit tidak secara signifikan mempengaruhi ARL. Analisis tambahan memperkaya temuan hasil penelitian adanya karakteristik unik dalam hal monitoring maupun expropriation effects kepemilikan keluarga terhadap ARL bahwa sampai dengan tingkat kepemilikan tertentu, anggota keluarga melaksanakan fungsi pengawasan secara baik dan dapat menerbitkan la poran keuangan auditan secara lebih cepat.

Kata Kunci: $\quad$ Kepemilikan Keluarga; Dewan Komisaris; Komisaris Independen; Komite Audit; Audit Report Lag.

\section{Family Ownership, Corporate Governance, and Audit Report Lag}

\section{ABSTRACT}

The governance of family companies is still a concern for investors and other stakeholders. This study examines the effect of family ownership and corporate governance on audit report lag (ARL). The research sample is a non-financial company with a dominant family ownership and listed on the Indonesia Stock Exchange for the 2017-2019 period. Using the usual least squares analysis method and multiple regression techniques, the results showed that family ownershipand the number of commissioners were able to encourage auditors to complete audit reports faster. Meanwhile, the presence of independent commissioners and audit committees does not significantly affect ARL. Additional analysis enriches the research findings that there are unique characteristics in terms of monitoring and expropriation effects of family ownership on ARL that up to a certain level of ownership, family members carry out the supervisory function well and can issue audited financial reports more quickly.

Keywords: $\quad$ Family Ownership; Board of Commissioners; Independent Commissioner, Audit Committee; Audit Report Lag.

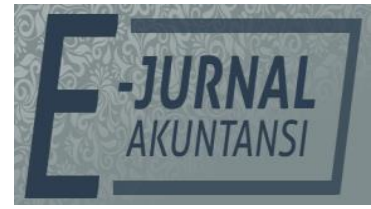

e-ISSN 2302-8556

Vol. 31 No. 11

Denpasar, November 2021

Hal. 2718-2735

DOI:

10,24843/EJA.2021,v31,i11,p04

PENGUTIPAN:

Alvianti, U., Moertono, B. Rusmin, R., \& Astami E. W. (2021). Kepemilikan Keluarga, Tata Kelola Perusahaan, dan Audit Report Lag. E-Jurnal Akuntansi, 31(11), 2718-2735

RIWAYAT ARTIKEL: Artikel Masuk: 16 Juli 2021 Artikel Diterima: 4 November 2021

Artikel dapat diakses: https:/ / ojs.unud.ac.id/index.php/Akuntansi/index 


\section{PENDAHULUAN}

Informasi akuntansi yang dapat diandalkan oleh pemakai eksternal (investor, kreditur, dan pemerintah) berasal dari laporan keuangan auditan yang disajikan dalam laporan tahunan perusahaan (Alkhatib \& Marji, 2012). Alfraih (2016) dan Alkhatib \& Marji (2012) mengatakan bahwa ketepatan waktu (timeliness) penyampaian laporan keuangan menjadi syarat penting agar informasi keuangan relevan untuk pengambilan keputusan. Keterlambatan penyampaian laporan keuangan akan mengurangi kualitas informasi karena meningkatkan ketidakpastian, kebocoran informasi, dan rumor-rumor di pasar saham yang dapat merugikan perusahaan (Alfraih, 2016). Selain itu, keterlambatan penyampaian laporan keuangan menyebabkan perusahaan dikenakan sanksi administrasi oleh Otoritas Jasa Keuangan (OJK). Surat keputusan Bursa Efek Indonesia Nomor Kep-00015/BEI/01-2021 mengharuskan perusahaan publik di Indonesia menyampaikan laporan keuangan tahunan paling lambat pada akhir bulan ke-3 (ketiga) setelah tanggal Laporan Keuangan Auditan Tahunan. Otoritas Jasa Keuangan melalui Siaran Pers: SP 18/DHMS/OJK/III/2020 menyatakan bahwa OJK melonggarkan batas waktu penyampaian laporan dan pelaksanaan Rapat Umum Pemegang Saham (RUPS) bagi pelaku industri Pasar Modal sebagai upaya menyesuaikan dengan kondisi darurat akibat virus Corona di Indonesia yang diperpanjang selama 2 (dua) bulan untuk laporan keuangan tahunan periode yang berakhir 31 Desember 2020, Namun ketentuan ini tidak berdampak pada sampel perusahaan yang kami teliti. Penelitian ini menggunakan sampel laporan keuangan perusahaan periode tahun 2017-2019,

Data mengenai penyampaian laporan keuangan sebelum kondisi darurat akibat virus Corona di negara Indonesia menunjukkan bahwa keterlambatan penyampaian laporan keuangan auditan masih terjadi pada beberapa perusahaan di Indonesia. Bursa Efek Indonesia mengumumkan sampai dengan 31 Juli 2020 terdapat 30 emiten yang belum menyampaikan laporan keuangan auditan untuk tahun buku yang berakhir 31 Desember 2019, Keterlambatan penyampaian laporan keuangan mengindikasikan terdapat masalah pada perusahaan sehingga membutuhkan waktu lebih lama bagi auditor menyelesaikan pekerjaan audit (Jao \& Crismayani, 2018). Beberapa faktor yang mempengaruhi penyelesaian laporan hasil audit, antara lain, reputasi auditor, spesialisasi auditor, tata kelola, kompleksitas, ukuran, leverage, profitabilitas, jenis industri perusahaan yang diaudit (Habib \& Bhuiyan, 2011), (Rusmin \& Evans, 2017), dan (Dufrisella \& Utami, 2020).

Penelitian tentang ARL sudah dilakukan di berbagai Negara, namun hasil penelitian masih belum konklusif dan belum memfokuskan pada perusahaan keluarga. Seperti halnya penelitian yang dilaksanakan di Nigeria (Ilaboya \& Christian, 2014) dan (Azubike \& Aggreh, 2014), Malaysia (Apadore \& Noor, 2013; Apadore \& Yusof, 2020) dan (Kaaroud et al., 2020), New Zealand (Habibet al., 2018) Hongkong (Jaggi \& Tsui, 1999), Amerika Serikat (Ghosh \& Tang, 2015), Palestina (Hassan, 2016) dan Italia (Sakka \& Jarboui, 2016) tidak banyak yang menguji pengaruh kepemilikan keluarga terhadap ARL. Kenyataannya, bisnis keluarga menyumbang $25 \%$ pendapatan nasional bruto Indonesia dan $95 \%$ bisnis di Indonesia didominasi oleh perusahaan milik keluarga (CNN Indonesia, 2014). Oleh karena itu, perusahaan keluarga mengambil peran yang sangat penting 
dalam perekonomian Indonesia (PwC, 2014). Demikianjuga, Claessens et al. (2000) melaporkan bahwa concentrated ownership beberapa perusahaan di Indonesia paling tinggi dibanding dengan concentrated ownership pada perusahaanperusahaan di Negara Asia Timur lainnya.

Penelitianini menggunakam teori keagenan (agency theory) dan teori sinyal (signaling theory) sebagai landasan dalam menjelaskan pengaruh kepemilikan keluarga dan tata kelola dengan ARL. Hubungan keagenan seringkali menyebabkan timbulnya masalah keagenan (agency problem) yaitu konflik kepentingan antara manajemen dan pemilik perusahaan sebagai akibat ketidaksamaan tujuan (Astami \& Tower, 2006) dan (Jensen \& Meckling, 1976). Jensen \& Warner (1988) menyatakan bahwa struktur kepemilikan perusahaan menentukan karakteristik masalah keagenan. Untuk meminimalisasi masalah keagenan ini dibutuhkan peran auditor independen guna mengurangi perilaku manajemen dalam melakukan tindakan yang tidak sejalan dengan tujuan perusahaan dan membantu penyelesaian laporan keuangan auditan tepat waktu (Lukviarman, 2016).

Teori sinyal menjelaskan hubungan antara manajemen dan pihak luar (investor) yang berkaitan dengan tindakan perusahaan dalam menyampaikan informasi keuangan auditan kepada para pengguna untuk mengambil keputusan bisnis dan ekonomi (Ni'mah \& Triani, 2021). Penyampaian laporan keuangan auditan menimbulkan reaksi pasar modal yang bisa berdampak pada harga saham perusahaan (Firmansyah \& Amanah, 2020). Menurut Kuslihaniati \& Hermanto (2016) apabila pasar mengindikasikan terdapat sinyal positif maka berdampak pada kenaikan harga saham, sebaliknya apabila pasar menangkap sebagai sinyal negatif maka mengakibatkan penurunan harga saham perusahaan. Dengan demikian, perusahaan yang ARLnya lebih cepat akan memberi sinyal yang baik atau positif kepada para pengguna (investor), sedangkan perusahaan yang $A R L$ nya lebih lama akan memberi sinyal buruk atau negatif kepada para investor (Ni'mah \& Triani, 2021).

Kehadiran perusahaan keluarga bisa berdampak positif dan negatif. Para pendukung perusahaan keluarga mengatakan bahwa para pendiri (founders) memiliki komitmen yang tinggi untuk mempertahankan reputasi dan kinerja keuangan perusahaan agar dapat diwariskan kepada generasi penerus. Oleh karena itu, para pendiri (founders) cenderung mendorong anggota keluarga untuk melakukan pengawasan lebih ketat terhadap manajemen sehingga bisnis perusahaan menjadi sehat dan memungkinkan untuk menerbitkan laporan keuangan tepat waktu (Lumpkin \& Brigham, 2011). Beberapa hasil penelitian mendukung argumen positif ini. Hapsari \& Laksito (2019), misalnya, mengungkapkan bahwa kepemilikan keluarga berpengaruh signifikan secara negatif terhadap ARL. Sophiani (2018) juga membuktikan bahwa perusahaan yang dimiliki oleh anggota keluarga menyampaikan laporan keuangan auditan relatif lebih cepat dibanding perusahaan non-keluarga. Hal ini disebabkan karena auditor mendapat tekanan yang lebih besar untuk menyelesaikan audit dan menerbitkan laporan tepat waktu. Hasil tersebut juga dibuktikan oleh Lourenço et al. (2018) yang melaporkan bahwa $A R L$ perusahaan keluarga lebih pendek dibanding dengan perusahaan bukan milik keluarga. Hipotesis kami penelitian ini mengacu pada argumen positif ini. 
$\mathrm{H}_{1}$ : Perusahaan kepemilikan keluarga berpengaruh negatif terhadap ARL.

Tugas utama dewan komisaris adalah memberi masukan serta melakukan pengawasan terhadap kinerja manajemen. Semakin banyak anggota dewan komisaris, semakin ketat pengawasan terhadap kebijakan dan pengeloaan manajemen, yang pada akhirnya bisa meningkatkan kinerja perusahaan (Pervitasari, 2018). Penelitian tentang hubungan antara jumlah anggota dewan komisaris dan ARL tidak menyimpulkan hasil yang konklusif. Butarbutar \& Hadipratjitno (2017) melaporkan semakin banyak anggota dewan komisaris maka semakin pendek $A R L$. Hal ini disebabkan pelaksanaan pengawasan menjadi semakin efektif sehingga kinerja dan kualitas informasi laporan keuangan menjadi lebih baik yang berakibat memperpendek ARL. Namun, kesimpulan di atas berbeda dengan hasil penelitian Mak \& Li (2001), Beasley (1996), dan Ahmed \& Ahmad (2016) yang menyimpulkan bahwa jumlah anggota dewan komisaris yang terlalu besar menimbulkan masalah komunikasi dan koordinasi sehingga memperpanjang ARL. OLeh karena itu, hipotesis kami kedua sebagai berikut.

$\mathrm{H}_{2}$ : Semakin banyak jumlah anggota dewan komisaris maka semakin pendek ARL.

Berdasarkan teori keagenan, dewan komisaris independen bisa mengurangi masalah moral hazard sebagai akibat benturan kepentingan antara pemegang saham dan manajemen (Bliss, 2011) dan (Rusmanto \& Herlina, 2020). Carcello et al. (2002) berpendapat bahwa independensi dewan komisaris diperlukan agar dapat melaksanakan fungsi pengawasan secara profesional. Dewan komisaris independen mampu menjalankan fungsi pengawasan terhadap kinerja manajemen secara obyektif sehingga memperkecil risiko audit. Selanjutnya memungkinkan auditor membatasi ruang lingkup audit yang berdampak mempersingkat waktu pelaporan hasil audit (Pervitasari, 2018). Lebih lanjut, kehadiran dewan komisaris independen dapat mempengaruhi sifat, saat dan lingkup audit yang mengarah pada penerbitan laporan auditor tepat waktu (Alfraih, 2016). Penelitian yang dilakukan Afify (2009), Apadore \& Noor (2013), dan Sakka \& Jarboui (2016) mengkonfirmasi bahwa dewan komisaris independen mampu mengurangi risiko keterlambatan dalam pelaporan keuangan. Berdasarkan argumentasi tersebut, hipotesis kami yang ketiga sebagai berikut.

$\mathrm{H}_{3}$ : Semakin besar proporsi dewan komisaris independen pada perusahaan maka semakin pendek durasi atas ARL.

Komite audit memiliki peran penting dalam proses pelaporan keuangan dengan cara membantu tugas dewan komisaris untuk memastikan (1) kewajaran penyajian laporan keuangan sesuai standar akuntansi keuangan yang berlaku, (2) efektifitas penerapan pengendalian internal entitas, serta (3) pekerjaan auditor dalam mengaudit laporan keuangan berjalan lancar (Firmansyah \& Amanah, 2020). Pengawasan oleh komite audit diharapkan mempercepat penyelesaian laporan keuangan auditan sehingga dapat disampaikan tepat waktu (Rahayu \& Laksito, 2020). Lebih lanjut Naimi et al. (2010) mengatakan bahwa semakin banyak jumlah anggota komite audit menyebabkan tata-kelola dan sistem pengawasan terhadap keuangan perusahaan semakin baik. Pendapatini didukung oleh Atmojo \& Darsono (2017) yang mengkonfirmasi bahwa kehadiran komite audit berpengaruh negatif dan signifikan terhadap $A R L$. Argumen tersebut melandasi hipotesis kami yang keempat. 
$\mathrm{H}_{4}$ : Semakin banyak jumlah anggota komite audit pada perusahaan maka semakin pendek durasi untuk ARL.

\section{METODE PENELITIAN}

Studi ini fokus pada perusahaan non-keuangan dengan kepemilikan keluarga dan terdaftar di IDX. Penelitian ini menggunakan sampel perusahaan keluarga yang terdaftar di IDX untuk periode 2017-2019, Penentuan perusahaan keluarga dimulai dari informasi konglomerat Indonesia yang dimuat dalam Majalah Globe Asia Edisi Juli 2019, Selanjutnya, informasi setiap perusahaan ditelusuri secara manual untuk menemukan entitas-entitas yang termasuk dalam grup perusahaan yang dimiliki oleh konglomerat yang terdaftar di IDX. Dari perusahaan yang menerbitkan laporan keuangan berturut-turut selama tahun 2017 sampai 2019, terdapat 62 perusahaan atau 186 observasi (selama tiga tahun). Dari jumlah tersebut terdapat 17 observasi yang memiliki karakteristik unik dan ekstrim (outlier) dan dikeluarkan dari sampel penelitian. Dengan demikian, sampel akhir penelitian ini adalah 169 observasi. Rincian observasi yang disajikan menurut kelompok industri dilaporkan pada Tabel 1,

Tabel 1. Rincian Observasi Per Kelompok Industri

\begin{tabular}{lcc}
\hline \multicolumn{1}{c}{ Industri } & $\mathrm{N}$ & $\%$ \\
\hline Pertanian & 9 & 5,33 \\
Pertambangan & 17 & 10,06 \\
Industri Dasar \& Kimia & 28 & 16,57 \\
Aneka Industri & 11 & 6,51 \\
Industri Barang Konsumsi & 29 & 17,16 \\
Properti, Real Estate \& Konstruksi Bangunan & 46 & 27,22 \\
Infrastruktur, Utilitas \& Transportasi & 9 & 5,33 \\
Perdagangan, Jasa \& Investasi & 20 & 11,83 \\
Jumlah & 169 & 100,00 \\
\hline
\end{tabular}

Sumber: Data Penelitian, 2021

Dari Tabel 1 melaporkan bahwa sebagian besar perusahaan yang diteliti termasuk dalam kelompok industri Properti, Real Estate \& Konstruksi Bangunan, yaitu 46 perusahaan atau 27,22\%. Data ini juga berarti bahwa bisnis keluarga (family business) di Indonesia sebagian besar bergerak pada sektor Properti, Real Estate \& Konstruksi Bangunan. Penelitian kami menggunakan variabel dependen audit report lag (ARL) yaitu jumlah hari yang dibutuhkan oleh auditor untuk menyelesaikan suatu penugasan audit. ARL dihitung sejak tanggal akhir tahun buku perusahaan sampai dengan tanggal laporan auditor (Rusmin \& Evans, 2017). Dua variabel independen adalah kepemilikan keluarga dan tata-kelola (jumlah anggota dewan komisaris, proporsi anggota dewan komisaris independen, dan jumlah anggota komite audit). Seperti penelitian-penelitian sebelumnya La Porta et al. (1999) dan Faccio \& Lang (1984) kami menentukan kepemilikan keluarga apabila pemegang saham pengendali adalah anggota keluarga dan memiliki minimal $10 \%$ hak suara atau saham perusahaan. Informasi pemegang saham keluarga diperoleh dari daftar perusahaan milik konglomerat yang terdapat pada artikel di majalah Globe Asia edisi Juli 2019, Penelitian ini juga memasukkan reputasi auditor, ukuran perusahaan, dan klasifikasi industri sebagai variabel kontrol. Definisi operasional variabel penelitian disajikan pada Tabel 2. 


\section{Tabel 2. Definisi Operasional Variabel}

\begin{tabular}{|c|c|c|}
\hline Variabel & Definisi & Referensi \\
\hline ARL & $\begin{array}{l}\text { Jumlah hari sejaktanggal berakhir laporan keuangan } \\
\text { sampai dengan tanggal laporan auditor }\end{array}$ & $\begin{array}{l}\text { Alfraih (2016) dan } \\
\text { Reheul et al. (2013) }\end{array}$ \\
\hline FO & $\begin{array}{l}\text { Rasio saham yang dimiliki anggota keluarga } \\
\text { terhadap total saham yang beredar }\end{array}$ & $\begin{array}{l}\text { Chau \& Gray } \\
\text { (2010), La Porta et } \\
\text { al.(1999), dan } \\
\text { Faccio \& Lang } \\
\text { (1984) }\end{array}$ \\
\hline BSIZE & Jumlah anggota dewan komisaris & $\begin{array}{l}\text { Sakka \& Jarboui } \\
\text { (2016) dan } \\
\text { Pervitasari (2018) } \\
\text { Joened \& }\end{array}$ \\
\hline BIND & $\begin{array}{l}\text { Rasio anggota komisaris independen terhadap total } \\
\text { anggota dewankomisaris }\end{array}$ & $\begin{array}{l}\text { Damayanthi (2016) } \\
\text { dan Sidharta \& } \\
\text { Nurdina (2017) }\end{array}$ \\
\hline KA & Jumlah anggota komite audit & $\begin{array}{l}\text { Wan-Hussin \& } \\
\text { Bamahros (2013) } \\
\text { dan Afify (2009) }\end{array}$ \\
\hline RKAP & $\begin{array}{l}\text { Nilai } 1 \text { a pabila perusahaan diaudit oleh KAP yang } \\
\text { berafiliasi dengan Big- } 4 \text { dan } 0 \text { apabila diaudit oleh } \\
\text { KAP lain }\end{array}$ & $\begin{array}{l}\text { Rusmin \& Evans } \\
\text { (2017) dan } \\
\text { Pervitasari (2018) }\end{array}$ \\
\hline SIZE & Logaritma natural total aset & $\begin{array}{l}\text { Tanyi etal. (2010) } \\
\text { dan Habib \& } \\
\text { Bhuiyan (2011) }\end{array}$ \\
\hline KI & $\begin{array}{l}\text { Nilai } 1 \text { apabila perusahaan termasuk dalam } \\
\text { kelompok high profile industry (Pertanian, Industri } \\
\text { Pertambangan, Industri Dasar \& Kimia, Aneka } \\
\text { Industri, Industri Barang Konsumsi, dan } \\
\text { Infrastruktur, Utilitas \& Transportasi) dan diberi } \\
\text { nilai } 0 \text { apabila termasuk dalam kelompok industri } \\
\text { lain }\end{array}$ & $\begin{array}{l}\text { Rusmin \& Evans } \\
\text { (2017), Astami et al. } \\
\text { (2017), dan Hapsari } \\
\text { \& Laksito (2019) }\end{array}$ \\
\hline
\end{tabular}

Sumber: Data Penelitian, 2021

Penelitian menggunakan metode kuadrad terkecil biasa (ordinary least squares) dan teknik regresi berganda (multiple regressions technique) untuk menguii hipotesis yang diajukan. Model regresi didefinisikan dengan persamaan berikut. $A R L=\mathrm{a}+\beta_{1}(\mathrm{FO})+\beta_{2}(\mathrm{BSIZE})+\beta_{3}(\mathrm{BIND})+\beta_{4}(\mathrm{KA})+\beta_{5}(\mathrm{RKAP})+\beta_{6}(\mathrm{SIZE})+\beta_{7}(\mathrm{KI})+\varepsilon$ Keterangan:

$\mathrm{ARL} \quad=$ Audit Report Lag

$\beta_{1}-\beta_{7}=$ Koefisien regresi variabel independen dan variabel kontrol

FO = Kepemilikan keluarga (Family Ownership)

BSIZE = Jumlah anggota dewan komisaris

BIND = Proporsi dewan komisaris independent

KA = Jumlah anggota komite audit

RKAP = Reputasi KAP

SIZE = Ukuran perusahaan

KI $=$ Klasifikasi industri

$\varepsilon=$ Koefisien error 
HASIL DAN PEMBAHASAN

Tabel 3. ARL Menurut Kelompok Industri

\begin{tabular}{|c|c|c|c|c|c|c|}
\hline \multirow[b]{2}{*}{ Kelompok Industri } & \multirow{2}{*}{$\mathrm{n}$} & \multirow{2}{*}{$\%$} & \multicolumn{4}{|c|}{ Audit Report Lag (hari) } \\
\hline & & & Mean & Median & Min & $\operatorname{Max}$ \\
\hline Pertanian & 9 & 5,33 & 69 & 67 & 50 & 90 \\
\hline Pertambangan & 17 & 10,06 & 83 & 86 & 59 & 96 \\
\hline Industri Dasar \& Kimia & 28 & 16,57 & 78 & 80 & 50 & 114 \\
\hline Aneka Industri & 11 & 6,51 & 85 & 86 & 71 & 105 \\
\hline Industri Barang Konsumsi & 29 & 17,16 & 84 & 84 & 74 & 115 \\
\hline $\begin{array}{l}\text { Properti, Real Estate \& } \\
\text { Konstruksi Bangunan }\end{array}$ & 46 & 27,22 & 80 & 86 & 43 & 106 \\
\hline $\begin{array}{l}\text { Infrastruktur, Utilitas \& } \\
\text { Transportasi }\end{array}$ & 9 & 5,33 & 83 & 81 & 73 & 99 \\
\hline Perdagangan, Jasa \& Investasi & 20 & 11,83 & 81 & 82 & 66 & 97 \\
\hline Jumlah & 169 & 100,00 & 81 & 84 & 43 & 115 \\
\hline
\end{tabular}

Sumber: Data Penelitian, 2021

Rata-rata waktu penyelesaian audit $(A R L)$ terhadap laporan keuangan adalah 81 hari, yang paling pendek 69 hari terhadap perusahaan yang termasuk dalam kelompok industri "Pertanian". Sedangkan rata-rata penyelesaian audit paling lama adalah ketika auditor melaksanakan penugasan audit pada perusahaan kelompok "Aneka Industri" yaitu 85 hari. Selanjutnya, waktu penyelesaian audit paling cepat dan paling lambat masing-masing 43 hari (pada perusahaan "Properti, Real Estate \& Konstruksi Bangunan") dan 115 hari (pada perusahaan kelompok "Industri Barang Konsumsi"). Seperti yang dijelaskan, batas maksimum penyampaian laporan keuangan tahunan ditetapkan oleh OJK paling lama tiga bulan setelah tahun buku berakhir. Analisa tambahan yang kami lakukan menunjukkan bahwa terdapat 18 observasi atau lebih dari $10 \%$ sampel penelitian melampaui batas waktu penyampaian laporan hasil audit. Tabel 4 menyajikan hasil analisis statistik deskriptif variabel kotinyu (continuous variables) untuk variabel independen dan kontrol. Sedangkan variabel kontrol Reputasi Kantor Akuntan Publik (diaudit oleh KAP berafiliasi big-4 dan diaudit oleh KAP lain) dan Klasifikasi Industri (termasuk perusahaan high profile dan low profile). Tabel 4. Statistik Deskripsi Variabel Independen dan Kontrol

\begin{tabular}{lccccc}
\hline Variabel & Min & Max & Median & Mean & Std. Deviation \\
\hline $\begin{array}{l}\text { Kepemilikan } \\
\text { Keluarga (\%)(FO) }\end{array}$ & 19,69 & 92,40 & 59,95 & 62,35 & 16,88 \\
$\begin{array}{l}\text { Jumlah Dekom } \\
\text { (BSIZE) }\end{array}$ & 2,00 & 11,00 & 5,00 & 4,88 & 1,77 \\
$\begin{array}{l}\text { Independensi } \\
\begin{array}{l}\text { Dekom (BIND) } \\
\text { Jumlah Komite }\end{array}\end{array}$ & 20,00 & 100,00 & 40,00 & 41,51 & 9,95 \\
$\begin{array}{l}\text { Audit(KA) } \\
\text { Ukuran }\end{array}$ & 2,00 & 5,00 & 3,00 & 3,05 & 0,32 \\
$\begin{array}{l}\text { Perusahaan } \\
\text { Sumber: Data Penelitian, 2021 }\end{array}$ & 432,056 & $126,723,419$ & $9,369,892$ & $17,346,813$ & $21,604,515$ \\
\hline
\end{tabular}


Tabel 4, melaporkan rata-rata 62,35\% jumlah saham perusahaan yang beredar dimiliki oleh anggota keluarga (FO). Persentase kepemilikan keluarga paling kecil $(19,69 \%)$ pada PT Medco Energi Internasional Tbk tahun 2017 dan paling besar $(92,40 \%)$ adalah pada PT Sinar Mas Agro Resources \& Technology Tbk. Rata-ratajumlah anggota dewan komisaris (BSIZE) adalah 5 orang, minimum 2 orang dan maksimum 11 orang. Angka ini menunjukkan bahwa seluruh perusahaan yang diteliti telah memenuhi POJK No. 33 Tahun 2014 yang mewajibkan setiap perusahaan memiliki anggota dewan komisaris minimal 2 orang. Rata-rata proporsi dewan komisaris independen (BIND) sebesar 41,51\%, dengan proporsi paling rendah dan paling tinggi masing-masing 20,00\% dan $100,00 \%$. Angka ini menunjukkan bahwa sebagian besar perusahaan yang diteliti telah memenuhi PJOK No. 33 Tahun 2014 yang mewajibkan dewan komisaris independen minimal 30\%. Analisa tambahan yang dilakukan menunjukkan bahwa hanya satu perusahaan yang memiliki dewan komisaris independen di bawah 30\%. Tabel 4 juga melaporkan rata-rata anggota komite audit adalah 3 orang, minimum 2 orang dan maksimum 5 orang. PJOK No. 55 Tahun 2015 mewajibkan anggota komite audit paling sedikit 3 orang. Terdapat 4 observasi dalam sampel penelitian ini yang memiliki anggota komite audit sebanyak 2 orang. Rata-rata total aset perusahaan yang diteliti sebesar Rp17,346,813 juta. Perusahaan yang memiliki total aset paling kecil Rp432,056 adalah PT Ristia Bintang Mahkotasejati Tbk dengan total aset sebesar Rp432,056 juta pada tahun 2017, sementara PT Indah Kiat Pulp \& Paper Tbk memiliki total aset paling besar, yaitu Rp126,723,419 juta pada tahun 2018,

Tabel 5. Statistik Deskripsi Variabel RKAP dan KI

\begin{tabular}{lcc}
\hline & $\mathrm{n}$ & \% tase \\
\hline RKAP & & \\
1 = Diaudit oleh KAP berafiliasi Big-4 & 83 & 49,10 \\
0 = Diaudit oleh KAP lain & 86 & 50,90 \\
Klasifikasi Industri & & \\
1 = Termasuk perusahaan High Profile & 103 & 60,90 \\
$0=$ Termasukperusahaan Low Profile & 66 & 39,10 \\
\hline
\end{tabular}

Sumber: Data Penelitian, 2021

Tabel 5, melaporkan 83 observasi atau 49,10\% sampel penelitian diaudit oleh KAP yang berafiliasi dengan Big4, Sedangkan 103 observasi (60,90\%) sampel termasuk perusahaan dalam kelompok high profile industry, sisanya $(39,10 \%)$ adalah perusahaan yang dikategorikan sebagai low profile industry.

Tabel 6. Matrik Korelasi Pearson

\begin{tabular}{lccccccc}
\hline & FO & BSIZE & BIND & KA & RKAP & SIZE & KI \\
\hline ARL & $-0,155^{* *}$ & $-0,180^{* *}$ & $-0,039$ & 0,139 & 0,124 & $-0,109$ & 0,045 \\
FO & & $-0,215^{*}$ & 0,013 & 0,063 & $-0,208^{*}$ & $-0,369^{*}$ & 0,122 \\
BSIZE & & & $-0,085$ & 0,001 & $0,234^{*}$ & $0,361^{*}$ & 0,132 \\
BIND & & & & $-0,022$ & $-0,179^{* *}$ & 0,029 & $-0,142$ \\
KA & & & & & $0,186^{* *}$ & $-0,029$ & 0,080 \\
RKAP & & & & & & $0,359^{*}$ & $0,277^{*}$ \\
SIZE & & & & & & & $0,296^{*}$ \\
\hline
\end{tabular}

Sumber: Data Penelitian, 2021 
Tabel 7. Kepemilikan Keluarga, Tata Kelola, dan ARL

\begin{tabular}{|c|c|c|c|c|c|c|c|c|c|c|c|}
\hline & \multicolumn{2}{|c|}{ Panel A } & \multicolumn{2}{|c|}{ Panel B } & \multicolumn{2}{|c|}{ Panel C } & \multicolumn{2}{|c|}{ Panel D } & \multicolumn{3}{|c|}{ Panel E } \\
\hline & Beta & $t$-stat & Beta & $t$-stat & Beta & t-stat & Beta & t-stat & Beta & t-stat & $\begin{array}{l}\mathrm{VI} \\
\mathrm{F}\end{array}$ \\
\hline $\begin{array}{l}\text { (Consta } \\
n t)\end{array}$ & & $8,888^{*}$ & & $\begin{array}{c}8,520 \\
*\end{array}$ & & $\begin{array}{c}8,403 \\
*\end{array}$ & & $\begin{array}{c}5,759 \\
*\end{array}$ & & $\begin{array}{c}6,652 \\
*\end{array}$ & \\
\hline FO & $\begin{array}{c}- \\
0,18 \\
5\end{array}$ & $-2,940 *$ & & & & & & & $\begin{array}{c}- \\
0,20 \\
6\end{array}$ & $\begin{array}{c}- \\
3,309 \\
*\end{array}$ & $\begin{array}{l}1,2 \\
86\end{array}$ \\
\hline BSIZE & & & $\begin{array}{c}- \\
1,34 \\
5\end{array}$ & $\underset{* *}{-} \underset{*}{2,307}$ & & & & & $\begin{array}{c}- \\
1,50 \\
2\end{array}$ & $\begin{array}{c}- \\
2,634 \\
*\end{array}$ & $\begin{array}{l}1,1 \\
83\end{array}$ \\
\hline BIND & & & & & $\begin{array}{c}0,00 \\
8\end{array}$ & 0,079 & & & $\begin{array}{c}- \\
0,00 \\
2\end{array}$ & $\begin{array}{c}- \\
0,021\end{array}$ & $\begin{array}{l}1,0 \\
70\end{array}$ \\
\hline KA & & & & & & & $\begin{array}{c}3,95 \\
3\end{array}$ & 1,297 & $\begin{array}{c}4,46 \\
0\end{array}$ & 1,519 & $\begin{array}{l}1,0 \\
55\end{array}$ \\
\hline RKAP & $\begin{array}{c}3,60 \\
0\end{array}$ & 1,734 & $\begin{array}{c}5,04 \\
4\end{array}$ & $\underset{* *}{2,415}$ & $\begin{array}{c}4,51 \\
1\end{array}$ & $\underset{* *}{2,106}$ & $\begin{array}{c}3,93 \\
3\end{array}$ & 1,839 & $\begin{array}{c}3,50 \\
6\end{array}$ & 1,653 & $\begin{array}{l}1,3 \\
20\end{array}$ \\
\hline SIZE & $\begin{array}{c}- \\
2,73 \\
9\end{array}$ & $\begin{array}{c}- \\
3,243 \\
*\end{array}$ & $\begin{array}{c}- \\
1,22 \\
9\end{array}$ & $\begin{array}{c}- \\
1,488\end{array}$ & $\begin{array}{c}- \\
1,80 \\
3\end{array}$ & 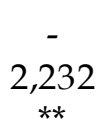 & $\begin{array}{c}- \\
1,67 \\
6\end{array}$ & $\begin{array}{c}- \\
2,089 \\
* *\end{array}$ & $\begin{array}{c}- \\
2,07 \\
7\end{array}$ & $\begin{array}{c}- \\
2,394 \\
* *\end{array}$ & $\begin{array}{l}1,5 \\
46\end{array}$ \\
\hline KI & $\begin{array}{c}3,13 \\
1\end{array}$ & 1,460 & $\begin{array}{c}1,36 \\
9\end{array}$ & 0,659 & $\begin{array}{c}1,36 \\
3\end{array}$ & 0,641 & $\begin{array}{c}1,19 \\
3\end{array}$ & 0,567 & $\begin{array}{c}3,18 \\
8\end{array}$ & 1,500 & $\begin{array}{l}1,2 \\
62\end{array}$ \\
\hline
\end{tabular}

Summ

ary

R-

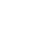


dan kontrol dan antar variabel kontrol menunjukkan bahwa korelasi yang paling tinggi adalah antara FO dan SIZE, dengan koefisen sebesar 0,369 ( $p<0,01)$. Namun, nilai koefisien ini di bawah batas kritikal 0,80,

Hasil analisis regresi linier berganda untuk menguji hipotesis 1 sampai 4 dilaporkan pada Tabel 7, Panel A sampai D menyajikan hasil regresi dengan satu variabel independen secara individual, sedangkan Panel E memasukkan seluruh variabel independen dalam regresi berganda. Estimasi model regresi pada Panel A sampai E secara statistik signifikan (F-statistic $p<0,05$ dan $p<0,01)$. Panel A dan E konsisten menunjukkan bahwa FO secara statistik dan signifikan $(p<0,01)$ berpengaruh negatif terhadap ARL. Oleh karenaitu, H1 terdukung. Semakin besar kepemilikan saham oleh anggota keluarga maka semakin pendek waktu yang diperlukan auditor untuk menyelesaian pekerjaan audit. Hasil penelitian ini konsisten dengan penelitian-penelitian terdahulu, misalnya Rusmin \& Evans (2017) dan Hapsari \& Laksito (2019). Keluarga memiliki orientasi jangka panjang dalam mempertahankan perusahaan untuk diwariskan kepada generasi penerus. Para pendiri (founders) selalu mendorong manajemen agar melakukan tindakan sejalan dengan kepentingan pemegang saham. Dengan demikian, operasional perusahaan menjadi sehat dan memungkinkan dapat menerbitkan laporan keuangan tepat waktu (Pinayungan \& Hadiprajitno, 2019). Wan-Hussin \& Bamahros (2013) dan Chan et al. (2016) juga berargumen bahwa semakin besar persentase kepemilikan saham memungkinkan keluarga melakukan pengawasan lebih ketat agar manajemen terus berkomitmen menjaga reputasi perusahaan dan mendorong auditor menyelesaikan penugasan audit tepat waktu. Demikian juga, koefisien BSIZE secara statistik signifikan $(\mathrm{p}<0,05$ dan $\mathrm{p}<0,01)$ berpengaruh negatif terhadap ARL (Panel B dan E). Oleh karena itu, H2 terdukung. Perusahaan keluarga yang memiliki anggota dewan komisaris lebih banyak dapat mempercepat laporan hasil audit, selanjutnya bisa menyampaikan laporan keuangan auditan tepat waktu. Temuan kami sama dengan hasil penelitian Joened \& Damayanthi (2016) dan Rusmanto \& Herlina (2020). Semakin banyak jumlah anggota dewan komisaris, semakin besar pula kemampuan mereka melakukan pengawasan terhadap efektifitas dan efisiensi pengendalian internal dan kegiatan operasional perusahaan (Sari et al., 2019) dan (Faishal \& Hadiprajitno, 2015), yang selanjutnya menurunkan tingkat risiko audit dan mengurangi audit report lag (Firmanti \& Arwina, 2020). Sesuai dengan agency theory, hasil penelitian kami mendukung bahwa kehadiran anggota keluarga dalam perusahaan dan peran dewan komisaris dapat mengurangi masalah keagenan (agency problem) dengan cara menyampaikan laporan keuangan auditan tepat waktu, akurat, dan menjamin prilaku manajemen yang sejalan dengan kepentingan perusahaan (Lukviarman, 2016). Hasil studi ini juga konsisten dengan teori sinyal (signaling theory) bahwa penyampaian laporan keuangan auditan yang tepat waktu memberi sinyal positif kepada pasar dan pada akhirnya bisa berdampak pada kenaikan harga saham perusahaan (Firmansyah \& Amanah, 2020) dan (Kuslihaniati \& Hermanto, 2016).

Panel C, D, dan E melaporkan koefisien BIND dan KA secara statistik tidak signifikan, dan oleh karenanya H3 dan H4 tidak terdukung. Penelitian kami tidak berhasil membuktikan kehadiran dewan komisaris independen dan komite audit pada bisnis keluarga mempercepat waktu penyelesaian audit. Rata-rata rasio 
dewan komisaris independen pada sample kami sebesar 41,51\% (lihat Tabel 4). Jumlah ini sedikit lebih besar dari batas minimum yang diwajibkan oleh PJOK No 3 Tahun 2014, sehingga keberadaan dewan komisaris independen ini terkesan sekedar memenuhi peraturan dan belum berdampak terhadap penyampaian laporan keuangan auditan (Tehupuring, 2016). Argumen yang sama juga pada komite audit. Rata-rata jumlah anggota komite audit sebanyak 3 orang (lihat Tabel 4). Jumlah ini sama dengan batas minimum yang diwajibkan oleh PJOK No 55/POJK.04/2015,

Berkaitan dengan variabel kontrol, penelitian ini tidak berhasil mengkonfirmasi bahwa kualitas audit KAP yang berafiliasi dengan Big4 lebih tinggi dibanding KAP lain. Salah satu penyebabnya kemungkinan pangsa pasar KAP level kedua (the second-tier international audit firms) seperti Moore Stephens International, BKR International, dan BDO International Limited meningkat drastis di Indonesia dan mereka selalu mempertahankan kualitas audit yang tinggi (Ali \& Aulia, 2015). Koefisien variabel SIZE negatif dan signifikan pada semua model regresi (Panel A sampai E), mendukung argumen bahwa perusahaan besar dapat menggunakan pengaruhnya mendorong auditor menyelesaikan penugasan audit tepat waktu. Kemungkinan lain, perusahaan besar memiliki sumber daya yang lebih (teknologi canggih, karyawan yang trampil, struktur pengendalian internal yang efektif), sehingga mempercepat auditor dalam menyelesaikan proses audit (Rusmin \& Evans, 2017). Terakhir, penelitian ini melaporkan bahwa jenis industri tidak menyebabkan waktu penyelesaian audit menjadi berbeda. Koefisien pada variabel KI pada semua model regresi adalah positif, namun secara statistik tidak signifikan. Seperti yang dijelaskan pada Tabel 6, bahwa tidak terdapat masalah multikolonieritas antar variabel yang diteliti. Variance inflation factor (VIF) adalah teknik lain untuk menguji multikolonieritas. Semua nilai VIF pada Tabel 7, di bawah 10 (Cooper \& Schinder, 2003), sehingga memberi bukti tambahan bahwa tidak terjadi masalah multikolonieritas pada hasil regresi linier berganda penelitian ini.

Tabel 8, menyajikan analisa tambahan yang mempertimbangkan dampak berbagai kelompok industri dan periode audit (industry and year effects) untuk mengkonfirmasi validitas temuan yang dilaporkan pada Tabel 7, Hasil pengujian Hausman (Hausman test) menyarankan kami menggunakan fixed-effect estimation untuk menguji dampak kedua faktor tersebut. Semua estimasi model regresi pada Tabel 8 signifikan (F-statistic, $\mathrm{p}<0,01$ ). Hasil regresi linier berganda fixed-effect test secara umum sama dengan temuan yang dilaporkan pada Tabel 7, Dengan kata lain, temuan kami pada Tabel 7, tidak dipengaruhi oleh sampel perusahaan pada kelompok industri atau tahun buku tertentu. Kepemilikan saham oleh keluarga bisa berdampak positif maupun negatif terhadap operasional perusahaan (Arosa et al., 2010) dan (Anderson \& Reeb, 2003). Apabila kepemilikan belum terkonsentrasi tinggi (highly concentrated) maka anggota keluarga menjalankan fungsi pengawasan dengan baik (monitoring hypothesis) dan segala tindakan sejalan dengan tujuan perusahaan. Oleh karena itu, berdampak positif pada kinerja perusahaan. Namun, ketika kepemilikan keluarga sangat dominan, hubungan antara kedua variabel tersebut menjadi negatiif. Pemegang saham mayoritas cenderung melakukan eksproriasi (enrenchement hypothesis) terhadap hak pemegang saham minoritas (Fan \& Wong, 2002). Kedua hipotesis ini membuat 
kami memprediksi terdapat hubungan yang tidak linier antara kepemilikan keluarga dan $A R L$.

Tabel 8. Kepemilikan Keluarga, Tata Kelola, dan ARL-Fixed Effects Regression

\begin{tabular}{|c|c|c|c|c|c|c|c|c|c|}
\hline & \multicolumn{3}{|c|}{ Panel A } & \multicolumn{3}{|c|}{ Panel B } & \multicolumn{3}{|c|}{ PanelC } \\
\hline & Beta & $t$-stat & VIF & Beta & t-stat & VIF & Beta & t-stat & VIF \\
\hline (Constant) & & $6,759^{*}$ & & & $5,724^{*}$ & & & $5,792^{*}$ & \\
\hline$F O$ & $\begin{array}{c}- \\
0,205\end{array}$ & $-3430^{*}$ & 1,286 & ${ }^{-}, 215$ & $-3,046^{*}$ & 1,720 & $\begin{array}{c}- \\
0,210\end{array}$ & $-3,111^{*}$ & 1,721 \\
\hline BSIZE & $\begin{array}{c}- \\
1,550\end{array}$ & $-2,819^{*}$ & 1,187 & $\begin{array}{c}- \\
1,284\end{array}$ & $\overline{-}^{-}, 168^{* *}$ & 1,327 & $\overline{-}$ & $2,322^{* *}$ & 1,331 \\
\hline BIND & 0,002 & 0,019 & 1,071 & 0, & $-0,152$ & 1,076 & $\begin{array}{c}- \\
0,011\end{array}$ & $-0,118$ & 1,078 \\
\hline$K A$ & 4,628 & 1,636 & 1,057 & 3,412 & 1,149 & 1,121 & 3,631 & 1,277 & 1,123 \\
\hline$R K A P$ & 3,751 & 1,836 & 1,321 & 4,699 & $2,089^{* *}$ & 1,544 & 5,073 & $2,354^{* *}$ & 1,548 \\
\hline SIZE & $2, \overline{140}$ & $-2,557^{*}$ & 1,552 & $\begin{array}{c}- \\
1,756\end{array}$ & $\begin{array}{c}- \\
2,024^{* *}\end{array}$ & 1,607 & $\begin{array}{c}- \\
1,830\end{array}$ & $2,-$ & 1,614 \\
\hline KI & 3,099 & 1,515 & 1,262 & & & & & & \\
\hline $\begin{array}{l}\text { Year } \\
\text { dummies }\end{array}$ & & Yes & & & No & & & Yes & \\
\hline $\begin{array}{l}\text { Industry } \\
\text { dummies } \\
\text { Summary }\end{array}$ & & No & & & Yes & & & Yes & \\
\hline R-Squared & & 0,215 & & & 0,206 & & & 0,215 & \\
\hline Adj. R-Sq. & & 0,171 & & & 0,140 & & & 0,171 & \\
\hline F-Statistic & & $4,849^{*}$ & & & $3,095^{*}$ & & & $4,011^{*}$ & \\
\hline Sample & & 169 & & & 169 & & & 169 & \\
\hline
\end{tabular}

Sumber: Data Penelitian, 2021

Demikian juga, Huther (1997) mengatakan bahwa anggota dewan komisaris yang terlalu banyak akan menimbulkan masalah koordinasi sehingga memperlambat pengambilan keputusan. Lipton \& Lorch (1992) membuktikan jumlah dewan komisaris yang paling efektif apabila kurang dari 10 orang. Sementara Jensen (1993) melaporkan komposisi dewan komisaris perusahaanperusahaan di Amerika cenderung terlalu besar dan beliau menyarankan anggota dewan komisaris tidak lebih dari 8 orang. Lebih lanjut, susunan dewan komisaris harus mempertimbangkan biaya dan manfaat fungsi pengawasan yang mereka lakukan (Linck et al., 2008). Sampai dengan jumlah tertentu, dewan komisaris dapat menjalankan tugas pengawasan secara efektif, namun lebih dari jumlah tersebut fungsi pengawasan yang mereka lakukan menjadi tidak optimal.

Oleh karena itu, kami menguji kemungkinan hubungan yang tidak linier (nonlinearities) pengaruh kepemilikan keluarga dan jumlah anggota dewan komisaris terhadap ARL (lihat Tabel 9). Panel A dan C menunjukkan bahwa FO berpengaruh negatif dan signifikan $(\mathrm{p}<0,01)$ terhadap ARL. Namun, FO-square berpengaruh positif dan signifikan $(p<0,05)$. Hasil ini mengkonfirmasi terjadi hubungan yang tidak linier antara kepemilikan keluarga dan ARL. Kepemilikan keluarga bisa menyebabkan prilaku yang berbeda. Pada tingkat pertama, penambahan persentase kepemilikan saham oleh anggota keluarga berd ampak positif pada kinerja perusahaan karena anggota keluarga menjalankan fungsi pengawasan secara ketat (mendukung monitoring hypothesis). Namun, di atas 
persentase ini, kinerja perusahaan mulai menurun oleh karena itu mendukung expropriation hypothesis. Pemegang saham mayoritas cenderung menggunakan posisinya yang dominan di perusahaan untuk mengambil manfaat bagi kepentingan mereka atas beban pemegang saham minoritas. Koefisien BSIZE dan BSIZE-Square negatif dan positif, namun hanya signifikan $(\mathrm{p}<0,05)$ pada Panel B. Oleh karena itu, tidak berhasil membuktikan hubungan tidak linier antara jumlah anggota dewan komisaris dan ARL.

Tabel 9. Hubungan Tidak Linier (Nonlinearities)

\begin{tabular}{|c|c|c|c|c|c|c|}
\hline & \multicolumn{2}{|c|}{ Panel A } & \multicolumn{2}{|c|}{ Panel B } & \multicolumn{2}{|c|}{ Panel C } \\
\hline & Beta & $\begin{array}{c}t- \\
\text { statistic }\end{array}$ & Beta & t-statistic & Beta & $\begin{array}{c}t- \\
\text { statistic }\end{array}$ \\
\hline (Constant) & & $6,970^{*}$ & & $6,735^{*}$ & & $7,113^{*}$ \\
\hline$F O$ & $-0,945$ & $-2,821^{*}$ & $-0,204$ & $-3,276^{*}$ & $-0,994$ & $-2,958^{*}$ \\
\hline FO-Square & 0,006 & $2,244^{* *}$ & & & 0,007 & $2,392^{* *}$ \\
\hline BSIZE & $-1,498$ & $-2,660^{*}$ & $-4,239$ & $-1,598$ & $-4,954$ & $-1,883$ \\
\hline BSIZE-Square & & & 0,248 & 1,057 & 0,314 & 1,344 \\
\hline BIND & $-0,002$ & $-0,025$ & 0,004 & 0,045 & 0,006 & 0,059 \\
\hline KA & 4,339 & 1,496 & 4,489 & 1,529 & 4,367 & 1,509 \\
\hline RKAP & 4,408 & $2,066^{* *}$ & 3,863 & 1,800 & 4,922 & $2,277^{* *}$ \\
\hline SIZE & $-2,219$ & $-2,582 *$ & $-1,906$ & $-2,161^{* *}$ & $-2,013$ & $-2,312^{* *}$ \\
\hline KI & 4,476 & $2,057^{* *}$ & 2,927 & 1,369 & 4,237 & $1,946^{* *}$ \\
\hline \multicolumn{7}{|l|}{ Summary } \\
\hline R-Squared & \multicolumn{2}{|c|}{0,169} & \multicolumn{2}{|c|}{0,148} & \multicolumn{2}{|c|}{0,178} \\
\hline Adj. R-Sq. & \multicolumn{2}{|c|}{0,127} & \multirow{2}{*}{\multicolumn{2}{|c|}{$\begin{array}{c}0,106 \\
3,483^{*}\end{array}$}} & \multicolumn{2}{|c|}{0,131} \\
\hline F-Statistic & \multicolumn{2}{|c|}{$4,055^{*}$} & & & \multicolumn{2}{|c|}{$3,823^{*}$} \\
\hline Sample & \multicolumn{2}{|c|}{169} & \multicolumn{2}{|c|}{$\begin{array}{c}3,483^{*} \\
169\end{array}$} & \multicolumn{2}{|c|}{169} \\
\hline
\end{tabular}

Sumber: Data Penelitian, 2021

\section{SIMPULAN}

Penelitian ini menguji pengaruh kepemilikan keluarga, peran tata kelola (jumlah anggota dewan komisaris, proporsi dewan komisaris independen, dan jumlah anggota komite audit) terhadap lamanya penyelesaian laporan hasil audit (audit report lag atau $A R L$ ). Hasil analisis menunjukkan bahwa $\mathrm{H} 1$ dan $\mathrm{H} 2$ terdukung, sedangkan $\mathrm{H} 3$ dan $\mathrm{H} 4$ tidak terdukung. Analisis tambahan kami mengkonfirmasi baik monitoring maupun expropriation effects kepemilikan keluarga terhadap ARL. Apabila persentase kepemilikan keluarga tidak terlalu besar, anggota keluarga melaksanakan fungsi pengawasan dengan baik dan sejalan dengan tujuan perusahaan, yang pada akhirnya bisa mempercepat penerbitan laporan keuangan auditan. Namun, ketika kepemilikan saham oleh anggota keluarga sangat dominan, manajemen keluarga menggunakan kekuasaannya untuk mengambil keuntungan yang berdampak pada penurunan kinerja perusahaan.

Sampel kami fokus pada perusahaan keluarga yang terdaftar di IDX. Penelitian selanjutnya bisa diperluas, misalnya membandingkan sampel perusahaan keluarga dan non-keluarga dan juga dengan perusahaan non-public. Penelitian berikutnya juga bisa menguji variabel prediktor lainnya (misalnya, spesialisasi auditor, kesehatan perusahaan, kompleksitas perusahaan, dan karakteristik perusahaan lainnya) terhadap ARL. Kepemilikan saham perusahaan 
sampai dengan jumlah tertentu yang memungkinkan pemilik bisa efektif mengawasi dan mengendalikan operasional perusahaan perlu didorong. Namun, otoritas pembuat kebijakan perlu mengatur batas maksimum kepemilikan saham perusahaan untuk menghindari kekuasaan yang sangat dominan pada individu, kelompok, atau institusi tertentu sehingga bisa merugikan pemegang saham minoritas.

\section{REFERENSI}

Afify, H. A. E. (2009). Determinants of audit report lag Does implementing corporate governance have any impact? Empirical evidence from Egypt. 10(1), 56-86, https:/ / doi.org/10,1108/09675420910963397,

Ahmed, M. I., \& Chea-Ahmad, A. (2016). Effects of corporate governance characteristics on audit report lags. International Journal of Economics and Financial Issues, 6(7), 159-164,

Al-Ajmi, J. (2008). Audit and reporting delays: Evidence from an emerging market. Advances in Accounting, Incorporating Advances in International Accounting, 24(2), 217-226, https:// doi.org/10,1016/j.adiac.2008,08,002,

Alfraih, M. M. (2016). Corporate governancemechanisms and audit delay in a joint audit regulation. Journal of Financial Regulation and Compliance, 24(3), 292-316, https:/ / doi.org/10,1108/JFRC-09-2015-0054,

Ali, S., \& Aulia, M. R. P. (2015). Audit firm size, auditor industry specialization and audit quality: An empirical study of Indonesian state-owned enterprises. Research Journal of Finance and Accounting, 6(22), 1-14,

Alkhatib, K., \& Marji, Q. (2012). Audit reports timeliness: Empirical evidence from Jordan. Procedia - Social and Behavioral Sciences, 62, 1342-1349, https:/ / doi.org/10,1016/j.sbspro.2012,09,229,

Anderson, R. C., \& Reeb, D. M. (2003). Public family ownership and firm performance: Evidence from S\&P 500, Journal of Finance, 58(3), 1301-1328,

Apadore, K., \& Noor, M. M. (2013). Determinants of audit report lag and corporate governance in Malaysia. International Journal of Business and Management, 8(15), 151-163, https:/ / doi.org/10,5539/ijbm.v8n15p151,

Apadore, K., \& Yusof, M. 'Ate. bin M. (2020). Board characteristics and audit report lag. Internatinal Journal of Mangement, 11(10), 1846-1860, https:/ / doi.org/10,34218/IJM.11,10,2020,172,

Arosa, B. T., Iturralde, \& Maseda, A. (2010). Ownership structure and firm performance in non-listed firms: Evidence from Spain. Jurnal of Family Business Strategy, 1, 88-96,

Astami, E. W., Rusmin, R., Hartadi, B., \& Evans, J. (2017). The role of audit quality and culture influence on earnings management in companies with excessive free cash flow. International Journal of Accounting \& Information Management, 25(1), 21-42, https:/ / doi.org/10,1108/IJAIM-05-2016-0059,

Astami, E. W., \& Tower, G. (2006). Accounting-policy choice and firm characteristics in the Asia Pacific region: An international empirical test of Costly Contracting Theory. The International Journal of Accounting, 41(1), 1-21, https:/ / doi.org/10,1016/j.intacc.2005,12,004,

Atmojo, D. T., \& Darsono. (2017). Analisis faktor-faktor yang berpengaruh terhadap audit report lag (Studi empiris pada perusahaan yang terdaftar di 
Bursa Efek Indonesia tahun 2013-2015). Diponegoro Journal of Accounting, 6(4), 1-15,

https:/ / ejournal3,undip.ac.id/index.php/accounting/article/view/18677

Azubike, J. U. B., \& Aggreh, M. (2014). Corporate governance and audit delay in Nigerian quoted companies. European Journal of Accounting Auditing and Finance Research, 2(10), 22-33,

Beasley, M. S. (1996). An empirical analysis of the relation between the board of director composition and financial statement fraud. The Accounting Review, $71(4), 443-465$,

Bliss, M. A. (2011). Does CEO duality constrain board independence? Some evidence from audit pricing. Accounting and Finance, 51(2), 361-380, https:/ / doi.org/10,1111/j.1467-629X.2010,00360,x.

Butarbutar, R. S. K., \& Hadipratjitno, P. B. (2017). Analisis faktor-faktor yang mempengaruhi terhadap audit report lag (Studi empiris pada perusahaan manufaktur yang terdaftar di Bursa Efek Indonesia tahun 2012-2015). Diponegoro Journal of Accounting, 6(3), 1-12,

Carcello, J. V., Hermanson, D. R., Neal, T. L., \& Riley, JR, R. A. (2002). Board characteristics and audit fees. Contemporary Accounting Research, 19(3), 365384, https:/ / doi.org/10,1506/CHWK-GMQ0-MLKE-K03V.

Chan, K. H., Luo, V. W., \& Mo, P. L. L. (2016). Determinants and implications of long audit reporting lags: evidence from China. Accounting and Business Research, 46(2), 145-166, https:/ /doi.org/10,1080/00014788,2015,1039475,

Chau, G., \& Gray, S. J. (2010). Family ownership, board independence and voluntary disclosure: Evidence from Hong Kong. Journal of International Accounting, Auditing and Taxation, 19(2), 93-109, https:/ / doi.org/10,1016/j.intaccaudtax.2010,07,002,

Claessens, S., Djankov, S., \& Lang, L. H.P. (2000). The separation of ownership and control in East Asian corporations. Journal of Financial Economics, 58, 81-112, https:/ / doi.org/10,1016/S0304-405X(00)00067-2,

CNN Indonesia. (2014). https:/ / www.cnnindonesia.com/ ekonomi/ 20141202100356-92-15176/ pwc95-persen-perusahaan-indonesia-adalah-bisnis-keluarga.

Cooper, D. ., \& Schindler, P. (2003). Business Research Method (ke-8). Boston: McGraw Hill Irwin.

Dufrisella, A. A., \& Utami, E. S. (2020). Pengaruh good corporate governance terhadap ketepatan waktu penyampaian laporan keuangan (Studi kasus pada perusahaan manufaktur di BEI). Jurnal Riset Akuntansi Mercu Buana, 6(1), 50-64, https://doi.org/10,26486/jramb.v6i1,1195,

Faccio, M., \& Lang, L. H. (1984). The ultimate ownership of Western European corporations. Journal of Financial Economics, 65(3), 365-395,

Faishal, M., \& Hadiprajitno, P. B. (2015). Pengaruh mekanisme good corporate governance terhadap audit report lag. Diponegoro Journal of Accounting, 4(4), $1-11$,

Fan, J. P. H., \& Wong, T. J. (2002). Corporate ownership structure and the informativeness of accounting earnings in East Asia. Journal of Accounting and Economics, 33, 401-425,

Firmansyah, R., \& Amanah, L. (2020). Pengaruh profitabilitas, good corporate 
governance, leverage, dan firm size terhadap audit reportlag. Jurnal Ilmu Dan Riset Akuntansi (JIRA), 9(3), 1-20, http:/ / jurnalmahasiswa.stiesia.ac.id/index.php/jira/article/view/2843

Ghosh, A. Al, \& Tang, C. Y. (2015). Assessing financial reporting quality of family firms: The auditors' perspective. Journal of Accounting and Economics, 60(1), 148, https:/ / doi.org/10,1016/j.jacceco.2015,03,002,

Habib, A., \& Bhuiyan, M. B. U. (2011). Audit firm industry specialization and the audit report lag. Journal of International Accounting, Auditing and Taxation, 20(1), 32-44, https:/ / doi.org/10,1016/j.intaccaudtax.2010,12,004,

Habib, A., Bhuiyan, M. B. U., Huang, H. J., \& Miah, M. S. (2018). Determinants of audit report lag: A meta-analysis. International Journal of Auditing, 23(1), 2044, https:// doi.org/10,1111/ijau.12136,

Hapsari, M. W., \& Laksito, H. (2019). Pengaruh reputasi auditor dan spesialisasi industri auditor terhadap audit report lag (Studi empiris pada perusahaan manufaktur yang terdaftar di BEI tahun 2016 dan 2017). Diponegoro Journal of Accounting, 8(2), 1-14,

Hassan, Y. M. (2016). Determinants of audit report lag: evidence from Palestine. Journal of Accounting in Emerging Economies, 6(1), 13-32, https:/ / doi.org/10,1108/JAEE-05-2013-0024,

Huther, J. (1997). An empirical test of the effect of boardsize on firm efficiency. Economics Letters, 54, 259-264,

Ilaboya, O. J., \& Christian, I. (2014). Corporate governance and audit report lag in Nigeria. Asian Academy of Management Journal of Accounting and Finance, 4(13), 172-180,

Jaggi, B., \& Tsui, J. (1999). Determinants of audit report lag: Further evidence from Hong Kong. Accounting and Business Research, 30(1), 17-28, https:/ / doi.org/10,1080/00014788,1999,9728921,

Jao, R., \& Crismayani, F. P. (2018). Pengaruh mekanisme corporate governance terhadap audit delay. Prosiding Seminar Hasil Penelitian (SNP2M), 87-92, www.idx.co.id.

Jensen, M. C. (1993). The modern industrial revolution, exit and the failure of internal control systems. Journal of Finance, 48, 831-880,

Jensen, Michael C, \& Meckling, W. H. (1976). Theory of the firm: Managerial behavior, agency costs and ownership structure. Journal of Financial Economics, 3(4), 305-360, https:/ /doi.org/10,1177/0018726718812602,

Jensen, Michael C, \& Warner, J. B. (1988). The distribution of power among corporate managers, shareholders, and directors. Journal of Financial Economics, 20, 3-24, https://doi.org/10,1016/0304-405X(88)90038-4,

Joened, J. A., \& Damayanthi, I. G. A. E. (2016). Pengaruh karakteristik dewan komisaris, opini auditor, profitabilitas, dan reputasi auditor pada timeliness of financial reporting. E-Jurnal Akuntansi Universitas Udayana, 14(1), 423-450,

Kaaroud, M. A., Ariffin, M. N., \& Ahmad, M. (2020). The extent of audit report lag and governance mechanisms: Evidence from Islamic banking institutions in Malaysia. Journal of Islamic Accounting and Business Research, 11(1), 70-89, https:/ / doi.org/10,1108/JIABR-05-2017-0069,

Kuslihaniati, D. F., \& Hermanto, S. B. (2016). Pengaruh praktik corporate governance dan karakteristik perusahaan terhadap audit report lag. Jurnal 
Ilmu Dan Riset Akuntansi, 5(2), 1-22,

La Porta, R., Lopez-de-Silanes, F., \& Shleifer, A. (1999). Corporate ownership around the world. The Journal of Finance, 54(2), 471-517,

Linck, J. S., Netter, J. M., \& Yang, T. (2008). The determinants of boards structure. Journal of Financial Ecomomics, 87, 308-328,

Lipton, M., \& Lorch, J. (1992). A modest proposal for improved corporate governance. The Business Lawyer, 48, 59-77,

Lourenço, I. C., Branco, M. C., \& Curto, J. D. (2018). Timely reporting and family ownership: the Portuguese case. Meditari Accountancy Research, 26(1), 170-192, https:/ / doi.org/10,1108/MEDAR-05-2016-0058,

Lukviarman. (2016). Corporate Governance. PT Era Adictra Intermedia.

Lumpkin, G. T., \& Brigham, K. H. (2011). Long-term orientation and intertemporal choice in family firms. Entrepreneurship: Theory and Practice, 35(6), 1149-1169, https: / / doi.org/10,1111/j.1540-6520,2011,00495,x.

Mak, Y. T., \& Li, Y. (2001). Determinants of corporate governance. Journal of Corporate Finance, 7(3), 236-256,

Naimi, M. N. M., Shafie, R., \& Wan-Hussin, W. N. (2010). Corporate governance and audit report lag in Malaysia. Asian Academy of Management Journal of Accounting and Finance, 6(2), 57-84,

Ni'mah, D. L., \& Triani, N. N. A. (2021). Pengaruh variabel profitabilitas, size, inherent risk, pertumbuhan perusahaan dan audit changes terhadap audit report lag. Jurnal Akuntansi Unesa, 9(2), 1-13,

Peraturan Otoritas Jasa Keuangan Nomor 33/PJOK.33/2014 Tentang direksi dan dewan komisaris emiten atau perusahaan publik.

Peraturan Otoritas Jasa Keuangan Nomor 55/POJK.04/2015 tentang pembentukan dan pedoman pelaksanaan kerja komite audit.

Pervitasari, D. A. (2018). Pengaruh good corporate governance dan reputasi auditor terhadap audit report lag (Studi empiris pada perusahaan yang terdaftar di Bursa Efek Indonesia periode 2015-2016). Skripsi Program Studi Sarjana Akuntansi Universitas Teknologi Yogyakarta.

Pinayungan, I. K., \& Hadiprajitno, P. B. (2019). Analisis pengaruh corporate governance terhadap audit report lag. Diponegoro Journal of Accounting, 8(4), $1-11$,

PwC. (2014). Survey bisnis keluarga. https://www.pwc.com/id/en/publications/assets/indonesia-reportfamily-business-survey-2014,pdf.

Rahayu, S. L., \& Laksito, H. (2020). Faktor-faktor yang berpengaruh terhadap audit delay. Diponegoro Journal of Accounting, 9(4), 1-12, https:/ / doi.org/10,21067/mbr.v4i1,4768,

Reheul, A.-M., Caneghem, T. Van, \& Verbruggen, S. (2013). Audit report lags in the Belgian non-profit Sector: An empirical analysis. Accounting and Business Research, 43(2), 138-158, https:/ / doi.org/10,1080/00014788,2013,777828,

Rusmanto, T., \& Herlina, M. (2020). The relationship between corporate governance and audit report lag: Evidence from Indonesian. Review of Economics Studies \& Research Virgil MAdgearu, 17(7), 3003-3013,

Rusmin, R., \& Evans, J. (2017). Audit quality and audit report lag: case of Indonesian listed companies. Asian Review of Accounting, 25(2), 191-210, 
https:/ / doi.org/10,1108/ARA-06-2015-0062,

Sakka, F. I., \& Jarboui, A. (2016). Audit reports timeliness: Empirical evidence from Tunisia. Cogent Business \& Management, 3(1), 1-13, https:/ / doi.org/10,1080/23311975,2016,1195680,

Sari, W. O. I. (2021). Pengaruh dewan komisaris terhadap audit report lag dengan kompleksitas audit sebagai pemoderasi. Conference on Economic and Business Innovation. 1-13, https: / / doi.org/10,1016/ s1366-0071(04)00058-0

Sidharta, R. Y., \& Nurdina. (2017). Pengaruh penerapan good corporate governance terhadap audit delay pada perusahaan otomotif dan komponennya di Bursa Efek Indonesia. Management \& Accounting Research Journal Global, 2(1), 1-8, http:/ / stieus.ejournal.web.id/index.php/stieus/article/view/107,

Sophiani, Q. N. A. (2018). Pengaruh konsentrasi kepemilikan dan kesulitan keuangan terhadap audit report lag (Studi empiris pada perusahaan yang terdapat di Bursa Efek Indonesia. Skripsi Program Studi Sarjana Akuntansi Universitas Teknologi Yogyakarta.

Tanyi, P., Ranghunanda, K., \& Barua, A. (2010). Audit report lags after voluntary and involuntary auditor changes. Accounting Horizons, 24(4), 671-688,

Tehupuring, R. (2016). Corporate governance, tax avoidance, audit delay dan nilai perusahaan (Studi empiris pada perusahaan perbankan di BEI periode 20102014). Jurnal Infestasi, 12(1), 85-97, https:/ / doi.org/10,21107/infestasi.v12i1,1803,

Wan-Hussin, W. N., \& Bamahros, H. M. (2013). Do investment in and the sourcing arrangement of the internal audit function affect audit delay? Journal of Contemporary Accounting and Economics, 9(1), 19-32, https:/ / doi.org/10,1016/j.jcae.2012,08,001, 